\title{
Growth Performance of Indigenouns Goat Breeds Through Grazing Supplemented with Graded Levels of Sweet Potato (Ipomoea Batatas) Silage in Loma Woreda, Southern Ethiopia
}

Yaekob Lomba Lorato ( $\nabla$ yakob.lorato@yahoo.com )

Wolaita Sodo University https://orcid.org/0000-0002-7839-8288

Amare Abera Alambo

Senior Experts and researcer in Buaro of Livestock Development

\section{Research Article}

Keywords: Growth Performance, Indigenous goat, Sweet Potato

Posted Date: April 12th, 2021

DOl: https://doi.org/10.21203/rs.3.rs-366504/v1

License: (c) (1) This work is licensed under a Creative Commons Attribution 4.0 International License.

Read Full License 


\title{
GROWTH PERFORMANCE OF INDIGENOUNS GOAT BREEDS THROUGH GRAZING SUPPLEMENTED WITH GRADED LEVELS OF SWEET POTATO (Ipomoea Batatas) SILAGE IN LOMA WOREDA, SOUTHERN ETHIOPIA
}

\author{
Yaekob Lorato', Amare Abera ${ }^{2}$
}

\begin{abstract}
Background: A study was carried out in Loma district of Southern part of Ethiopia that aimed to determine the effects of supplementation of graded levels of sweet potato vine silage on growth performances of grazing indigenous goat breeds. Loma district, the potential area for sweet potato production, that they practiced feeding sweet potato for animal feed shortage especially during dry season in the study area. Two hundred Sixteen indigenous yearling male local goats $(16.3 \pm 0.4 \mathrm{~kg})$ were randomly selected for on-farm feeding trial. The goats were blocked into four groups of fifty four animals based on their initial body weight. Dietary treatments were randomly assigned to each animal in the groups. Animals which were assigned randomly in each block were given to farmers. The treatment comprised of grazing alone as treatment 1 , grazing+78 $\mathrm{g}$ dry matter sweet potato silage as treatment 2 , grazing $+156 \mathrm{~g}$ dry matter sweet potato silage as treatment 3 , grazing $+234 \mathrm{~g}$ dry matter sweet potato silage as treatment 4 .

Results: The highest dry matter contents $(89.7 \%)$ were observed in final trial periods compared to initial and mid-term of trial periods. The average daily gain for Treatment 4 was higher $(\mathrm{P}<0.05)$ than those goats in Treatment 1 and Treatment 2. The weight gain for Treatment 3 and Treatment 4 were similar $(\mathrm{P}>0.05)$. About $96.7 \%$ of the respondents produce sweet potato.

Conclusions: In the current feeding trial study results indicated that, the increased supplementation of sweet potato vine silage revealed increased performance of grazing local goats. Intake of dry matter increased from $78 \%$ to $234 \%$ with increasing levels of sweet potato vine silage supplementation. There was higher average daily gain for the supplemented group (60, 80 and 97g/head/day in Treatment 2, Treatment 3 and Treatment 4, respectively) than nonsupplemented ones $(34.2 \mathrm{~g} / \mathrm{head} / \mathrm{day})$. Therefore, from these findings it is concluded that supplementation of sweet potato silage favors better growth rate however we need to work on improving the productivity of sweet potato and improve benefits of feeding to goats.
\end{abstract}

Keywords: Growth Performance, Indigenous Goat, Sweet Potato

\section{INTRODUCTION}

In Ethiopia, sweet potato is cultivated in most high land areas and now day its cultivation is expanding towards the low land part of the country. Sweet potato (I.batatas L) is a creeping plant 
with perennial vines and adventitious roots, which can be easily cultivated and is relatively drought resistant. Sweet potato roots are high- moisture feedstuffs that serve primarily as an energy source. Nutritionally, sweet potato tuber is a rich source of energy while the vines are a rich source of protein and vitamins. (1) also recommended that sweet potato vines has to be produced as forage throughout the year or conserved as silage or hay to overcome its short term availability. The young leaf of sweet potato is highly relished by livestock and is a valuable source of protein, vitamins, and minerals. Sweet potato vines, roots, or leaves can also be conserved for animals feed during surplus productions in the form of hay or silage for dry season (2).

Loma was among Dawuro zone in Southern Regional State with the potential area for sweet potato production. However, currently animal feed shortage is a more aggravated problem especially during dry season in both the highlands and low lands of the study area. Hence, conservation of the existing feed resources could be one of the possible solutions for copping the shortage during dry season which could result in improved animal productivity. In addition to this, information on the effects feeding graded level sweet potato vines silage as animal feed on growth performance and blood biochemistry were scantly especially for grazing goats under farmers' management condition. Therefore, the objective of the study was to determine the effects of supplementation of graded levels of sweet potato vine silage on growth performances of grazing local goats.

\section{MATERIALS AND METHODS}

\subsection{Description of Study Area}

The study was conducted at Loma woreda of Dawuro Zone in Southwestern parts of Ethiopia. The administrative center of Dawuro is Tercha, which is located at about $500 \mathrm{~km}$ at $7^{0} 09^{\prime} \mathrm{N}$ and 
$37^{0} 30^{\prime} E$ South west of Addis Ababa. The Loma woreda, have 95,257 cattle, 20245 sheep, 72,245 goats, 4545 horses, 1890 mules and 5986 donkeys. Maize, teff, variety of sweat potato, inset, soybean, wheat, cassava, and sorghums are among the dominant crops that grow in the area (3). Loma woreda was selected among Zonal woredas because of the large amount of goat populations and suitability for sweet potato production trends within woreda as both human and animal feeds. This is why the woreda is classified under nearly Kolla climatic conditions among the other woreda of the Zones and known by sweet potato production among the others.

\subsection{The feeding experiment}

The experiment was conducted in Ella Bacho, Gendo, Deneba, Bero Kebeles of the Loma Woreda in 54 farmers house that were purposely selected based on their performance status of sweet potato production and animal husbandry trends to determine the effects of sweet potato vine silage on growth performance of goats.

\subsubsection{Experimental feeds}

\subsubsection{Grazing land preparation}

The grazing land was rented from private grazing pasture which was available on the farmers' village. The rented grazing pasture land $(100 \mathrm{~m} * 100 \mathrm{~m})$ were protected and fenced for experimental goats to graze during feeding trial periods (90 days) starting from initial periods (20/01/2019) of the feeding trial up to final periods (20/04/2019).

\subsubsection{Sweet potato vines preparation}

The sweet potatoes were planted at the plot land obtained from households who were given the experimental goats based on agreement created. All necessary agronomic practice starting from seed bed preparation up to harvesting the tubers were strictly followed by researchers and farmers that had got experimental goat.

The variety used is that founds in study area called ' $G A D I S A$ ' and it was the most promising variety. Finally the required amount of vines and the roots were purchased from those farmers for silage preparations. 


\subsubsection{Silage preparation}

When the tuber become mature (90 days after transplanting), the vines were purchased and harvested. The vines had about $30 \% \mathrm{DM}$ at the time of ensiling and it was achieved through wilting for 1-4 hrs. The vines were chopped into small pieces $(2 \mathrm{~cm})$ and roots were used as additives to facilitate fermentation as the vines are low in easily fermentable carbohydrates. The roots were washed to remove dirt and cut in to small pieces using knife. Generally, the following methods of silage making procedures were applied and silage was prepared for experimental goats on fresh weight (648 kg) by using fertilizer bag (26) which was covered with plastic bag inside and not teared.

Sweet potato vines were chopped into $2 \mathrm{~cm}$ length and roots into small pieces with knife and mixing was done before ensiling

$20 \%$ of roots on fresh basis were added as carbohydrate sources to sweet potato vines to make $100 \mathrm{~kg}$ silage (4)

$>$ A fertilizer bag that had no pores inside were prepared and used at each household level

$>$ The mixed materials were packed in the fertilizer bag. The material was compressed to remove air from the inside. Care was taken not to tear the bag which was covered with plastic in the inside part

$>$ The top of the bag were tied with sisal twine.

$>$ The packed materials were stored in rat-proof storage places ensuring of proper termite control around the store.

The fertilizers bags were opened after four weeks of ensiling when silage was required.

\subsubsection{Experimental animals and treatment}

Two Hundred Sixteen (216) yearling indigenous male local kids with average initial weight of $16.3( \pm 0.4) \mathrm{kg}$ (Mean $\pm \mathrm{SE}$ ) were purchased from the local market. Goats were adapted to the experimental feeds for 15 days. One household was assigned for each treatment. The goat were weighed by using spring balance for three consecutive days after overnight fasting and the average of these was taken as initial weight. On other hand body weights were taken every 14 days during feeding trial periods to determine the final weight. To each of the household four goats were assigned randomly. Prior to randomly assigning the goat were blocked into four different groups of four animals based on initial body weight. The goats were treated for external and internal parasites with accarcide (stalidon) and Albendazole 300mg, respectively. 
The experimental goats that were initially blocked into four groups according to their initial body weight were, randomly assigned to one of the four sweet potato silage dietary treatment. The treatments were;

$\mathrm{T} 1=$ Grazing $($ control $)$

$\mathrm{T} 2=$ Grazing + sweet potato silage ( $80 \%$ vines: $20 \%$ root; $\mathbf{7 8} \mathbf{g}$ offer on DM basis)

$\mathrm{T} 3=$ Grazing + sweet potato silage ( $80 \%$ vines: $20 \%$ root; $\mathbf{1 5 6} \mathbf{g}$ offer on DM basis)

$\mathrm{T} 4=$ Grazing + sweet potato silage ( $80 \%$ vines: $20 \%$ root; $\mathbf{2 3 4} \mathbf{g}$ offer on DM basis)

The goats were grazing during the day time and supplemental feeds were weighed every morning and the animals were fed 50\% of their daily ration in the morning at 8:00am before they go for grazing and $50 \%$ in the afternoon at 6:00pm upon their return from grazing.

\subsubsection{Experimental design and treatment}

The experiment was conducted using RCBD based on their initial body weight. The goat was blocked based on their initial body weight and randomly assigned to the four treatments; four animals per households.

\subsubsection{Feeding trials and assigning experimental animals to treatment}

The experimental feeding trial was carried out on farm level at Loma woreda. The sheltering area was prepared on each farmer's house separately from others animals by using local materials available on farmers' area. Feeding and watering of experimental feed were done using watering and feeding troughs purchased from market for each animal. When silage is required the bag were opened and what is needed for the day only were removed. After removal, the bags were closed to avoid deterioration. The silage was fed individually. Totally the feeding trials were conducted for $\mathbf{9 0}$ days including adaptation periods. A preliminary period of 15 days were given to allow adjustment of the growing animals to diets, and followed by 75 days of feeding period. The supplemental feeds were weighed every morning and the animals were fed $50 \%$ of their daily ration in the morning before they go for grazing and 50\% in the afternoon upon their return from grazing. Salt were provided to each experimental animal every night ad libtum. The supplements were given at the same time every day. Water was offered overnight and they were also allowed to drink water from river during the day time while grazing. 


\subsubsection{Data management}

\subsubsection{Weight gain determination}

The animals were weighed on three consecutive days after evening fasting and the averages of these were taken the initial weight. Body weights were taken every 14 days after night fasting before letting them to grazing.

\subsubsection{Feed intake determination}

Amount of silage offered and refusal were measured to calculate feed intake. To do this, feed offered to experimental animals were weighed before offering and the refusals were collected from individual animals after the animals left for grazing and were weighed.

\section{3. Statistical analysis}

The data from growth trial such as feed intake, body weight change and blood parameters were subjected to analysis of variance using the General linear Model us (GLM) procedures of SAS Version 6.12(5). The means were compared with each other by using Duncan's multiple range tests. The statistical model was:

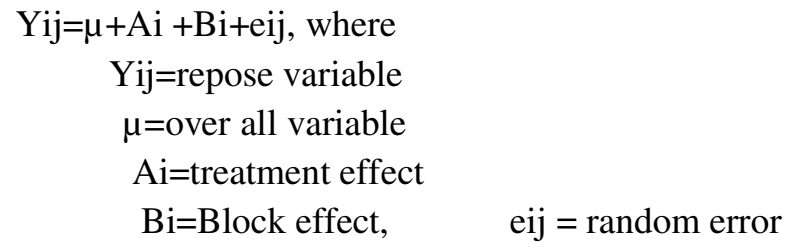

\section{RESULTS AND DISCUSSION}

\subsection{Feed resources availability of the study area}

The availability of feed resources is one of the determinant factors that concern by the owners of livestock. As survey indicates natural pastures, crop residues (Teff, maize, wheat, barley, and sorghum) fodder from trees and shrubs are the main feed resources in the study area (Table 1). Respondents indicated that a conservation technique of livestock feeds during dry season has got very small attentions. The result in Table 1 indicates, crop residues is the main feed resources in dry season 
Table 1: Feed resources available during Dry and Wet seasons in the study area $(\mathrm{N}=150)$

\begin{tabular}{lcc}
\hline & \multicolumn{2}{c}{ Seasons } \\
\cline { 2 - 3 } Feed Resources & Dry & Wet Frequency \\
& Frequency $(\%)$ & $(\%)$ \\
\hline Natural pasture & $46(30.7)$ & $119(79.3)$ \\
Crop residues & $80(53.3)$ & $25(16.7)$ \\
Fodder trees & $18(12)$ & $6(4.0)$ \\
Hay & $6(4.0)$ & - \\
$\quad$ Total & $150(100)$ & $150(100)$ \\
\hline
\end{tabular}

\subsection{The use of Sweet Potato as Livestock feed in the Study Area}

Households produce sweet potato primarily with the objectives of human consumption generally and livestock feed specifically (Table 2). Large percent of study area HHs had use sweet potato as livestock feed in different ways. As the report of the respondents indicate, most of the study area HHs offers sweet potato for livestock as a feed any time in a day $(75.3 \%)$ when available. A few $(16.7 \%)$ provides sweet potato as a feed during morning before the animals are left for grazing. It was reported that majority of the HHs offer sweet potato to their animals primarily as fresh, and followed in dried form. Almost all of the respondents suggested that sweet potato is mainly used in periods of feed shortages. Sweet potato vines, roots and leaves are used as animal feeds in study area. Sweet potato parts that were utilized for animal feed in study area are vines largely, followed by roots and leaves respectively. It was also mainly offered as feed primarily to cattle followed by equines and small ruminants.

Table 2: Percent $(\%)$ of Sweet potato utilization trends in the study area based on the respondents result $(\mathbf{N}=150)$ 


\begin{tabular}{cc}
\hline Measurements & \% response (N=150) \\
\hline Households growing Sweet potato & 96.7 \\
Households growing SP twice/year & 74 \\
Households growing SP once /year & 26 \\
Households using SP to LVSTK feed & 98.7 \\
Households offering SP Fresh form & 85.3 \\
Households offering SP Dried form & 14.7 \\
Households using SP during feed shortage & 94.3 \\
periods & \\
Households using SPV to LVSTK feed & 78 \\
Households using SPR to LVSTK feed & 15.3 \\
Households using SPL to LVSTK feed & 6.7 \\
Households feeding SP to Cattle & 74 \\
Households feeding SP to Equines & 14 \\
Households feeding SP to Small ruminants & 12 \\
\hline
\end{tabular}

\subsection{On-farm feeding trial on goat}

\subsubsection{Chemical composition and in vitro digestibility of grazed grass during the experiment}

The nutrient contents and in vitro digestibility are presented in Table 3. The DM contents of the grass used for grazing increased from the initial to Final trial periods. The highest DM contents were observed in final trial periods compared to initial and mid-term of trial periods. The $\mathrm{CP}$ content decreased with increasing stage of maturity of grasses. There was no significant change in NDF, ADF and ADL content during the different harvesting period. In vitro DM digestibility decreased as the trial period advanced.

Table 3: Mean Chemical composition (\%DM, unless specified) and in vitro digestibility of grasses harvested during different growth period

\begin{tabular}{cccc}
\hline & \multicolumn{2}{c}{ Grass harvesting period } \\
\cline { 2 - 4 } Parameter & Initial Trial Period & Mid Trial period & Final Trial period \\
DM & 45 & 59 & 89.7 \\
Ash & 14 & 12.5 & 11.8 \\
CP & 15.3 & 9.2 & 6.6 \\
NDF & 47.6 & 47 & 48.52 \\
ADF & 15.6 & 16.3 & 18.3 \\
ADL & 17.6 & 18.06 & 19 \\
EE & 16.3 & 10.6 & 8.1 \\
IVDMD & 77.1 & 72.4 & 65 \\
\hline
\end{tabular}

$\mathrm{DM}=$ Dry matter, $\mathrm{CP}=$ Crude protein, $\mathrm{NDF}=$ Neutral detergent fiber, $\mathrm{ADF}=$ Acid detergent fiber, $\mathrm{ADL}=\mathrm{Acid}$ detergent lignin, Ether Extract, IVDMD= In vitro DM digestibility

The CP contents observed by researchers (6) at open area match with the mean CP contents of this study at initial trial periods of the experiments but the CP contents at medium and final trial 
periods were relatively lower than the $\mathrm{CP}$ contents of closed areas, medium and low altitudes. The NDF and ADF contents of the grass was more or less similar across the sampling periods which disagree with the report of Tikuneh (7) but was similar to that of Tegene (6) who observed slightly similar results across the grass sampling periods .

\subsubsection{Chemical composition and in vitro digestibility of sweet potato Silage}

The Chemical composition and in vitro digestibility of sweet potato vine silage offered during feeding trials are presented in Table 4 . The sweet potato silage offered had moderate CP contents with high DM even if DM was below the optimum contents of good quality silage. The ADF, ADL and NDF contents of the SPVS was low.

Table 4: Chemical composition (DM \%, unless specified) and in vitro digestibility values of sweet potato vine silage used in the on-farm feeding trial

\begin{tabular}{lc}
\hline Parameter & Sweet potato vine silage(SPVS) \\
\hline DM & 26 \\
Ash & 10.5 \\
CP & 12 \\
NDF & 22.5 \\
ADF & 12.9 \\
ADL & 2.4 \\
EE & 43.2 \\
IVDMD & 85.2
\end{tabular}

$\mathrm{DM}=$ Dry matter, $\mathrm{CP}=$ Crude protein, $\mathrm{NDF}=$ Neutral detergent fiber, $\mathrm{ADF}=$ Acid detergent fiber, $\mathrm{ADL}=\mathrm{Acid}$ detergent lignin, $\mathrm{EE}=$ Ether Extract; $\mathrm{IVDMD}=$ In vitro $\mathrm{DM}$ digestibility

The DM \% and INVDMD \% of the silage in the present study was higher than the values $20 \%$ and $85 \%$, respectively for mean of four varieties sweet potato silage reported (8). The DM contents of the silage in present study is also higher than the value (15.2\%) reported (9) for sweet potato root and vine silage ensiled in proportion of SPR:SPV; 30:70. 


\subsubsection{The effect of feeding different levels of Sweet Potato vine Silage on feed intake of grazing goats.}

The mean values for intake of sweet potato vine silage by grazing local goats are shown in Table

5. The intake of DM, OM, CP, NDF, ADF and ADL increased $(\mathrm{P}<0.05)$ with increasing levels of SPVS Supplementation.

Table 5: Mean Daily Nutrient intake (g/h/day) of experimental goat fed graded level of sweet potato vine silage.

\begin{tabular}{cccc}
\hline & \multicolumn{3}{c}{ Treatments } \\
\cline { 2 - 4 } Intake & T2 & T3 & T4 \\
\hline DM & $\mathbf{7 8}^{\mathbf{c}}$ & $\mathbf{1 5 6}^{\mathbf{b}}$ & $209.4^{\mathrm{a}}$ \\
OM & $69.8^{\mathrm{c}}$ & $139.6^{\mathrm{b}}$ & $28.1^{\mathrm{a}}$ \\
CP & $9.4^{\mathrm{c}}$ & $18.7^{\mathrm{b}}$ & $52.9^{\mathrm{a}}$ \\
NDF & $17.6^{\mathrm{c}}$ & $35.3^{\mathrm{b}}$ & $30.1^{\mathrm{a}}$ \\
ADF & $10.1^{\mathrm{c}}$ & $20.1^{\mathrm{b}}$ & $5.6^{\mathrm{a}}$ \\
ADL & $1.9^{\mathrm{c}}$ & $3.7^{\mathrm{b}}$ & \\
\hline
\end{tabular}

\footnotetext{
${ }^{a b c}$ Means without common superscript letters within row are significantly different $(\mathrm{p}<0.05) \mathrm{DM}=\mathrm{d}$ ry matter, $\mathrm{OM}=$ organic matter, $\mathrm{CP}=$ crude protein, $\mathrm{NDF}=$ neutral detergent fiber, $\mathrm{ADF}=$ acid detergent fiber and $\mathrm{ADL}=\mathrm{acid}$ detergent lignin, $\mathrm{T} 2=$ grazing $+78 \mathrm{~g}$ sweet potato silage, $\mathrm{T} 3=$ grazing $+156 \mathrm{~g}$ sweet potato silage, $\mathrm{T} 4=$ grazing $+234 \mathrm{~g}$ sweet potato silage
}

\subsubsection{The effect of feeding different levels of Sweet Potato vine Silage on body weight change of grazing goats}

The weight gain of goats fed different levels of sweet potato vine silage is presented in Table 6 . The average daily gain for $\mathrm{T} 4$ was higher $(\mathrm{P}<0.05)$ than those goats in $\mathrm{T} 1$ and $\mathrm{T} 2$. The weight gain for $\mathrm{T} 3$ and $\mathrm{T} 4$ were similar $(\mathrm{P}>0.05)$.

Table6: Mean value for changes in live weight gain $(\mathrm{kg}$, unless specified) by experimental goat fed increasing level of sweet potato silage over feeding periods of 75 day

\begin{tabular}{|c|c|c|c|c|c|c|}
\hline Parameters & T1 & $\mathbf{T} 2$ & T3 & T4 & SEM & Pvalue \\
\hline Initial body weight & $16.3^{\mathrm{a}}$ & $16.3^{\mathrm{a}}$ & $16.3^{\mathrm{a}}$ & $16.3^{\mathrm{a}}$ & 0.4 & NS \\
\hline Final body weight & $18.8^{\mathrm{c}}$ & $20.8^{\mathrm{ab}}$ & $22.3^{\mathrm{ab}}$ & $23.6^{\mathrm{a}}$ & 0.8 & $* * *$ \\
\hline $\begin{array}{l}\text { Weight changes } \\
\text { gain }\end{array}$ & $2.6^{\mathrm{c}}$ & $4.5^{\mathrm{bc}}$ & $6^{\mathrm{ab}}$ & $7.3^{\mathrm{a}}$ & 0.6 & *** Average daily \\
\hline$(\mathrm{g} / \mathrm{head} / \mathrm{d})$ & $34.2^{\mathrm{c}}$ & $60^{\mathrm{bc}}$ & $80^{\mathrm{ab}}$ & $97^{\mathrm{a}}$ & 7.8 & $* * *$ \\
\hline
\end{tabular}


As the feeding period advanced animals were adapted more to feed which resulted in increased feed intake with increasing levels of supplementation and consequently increased body weight gain. Throughout the experimental period, the weight gain for T4 was higher than that of T1 and T2 (Figure 1).

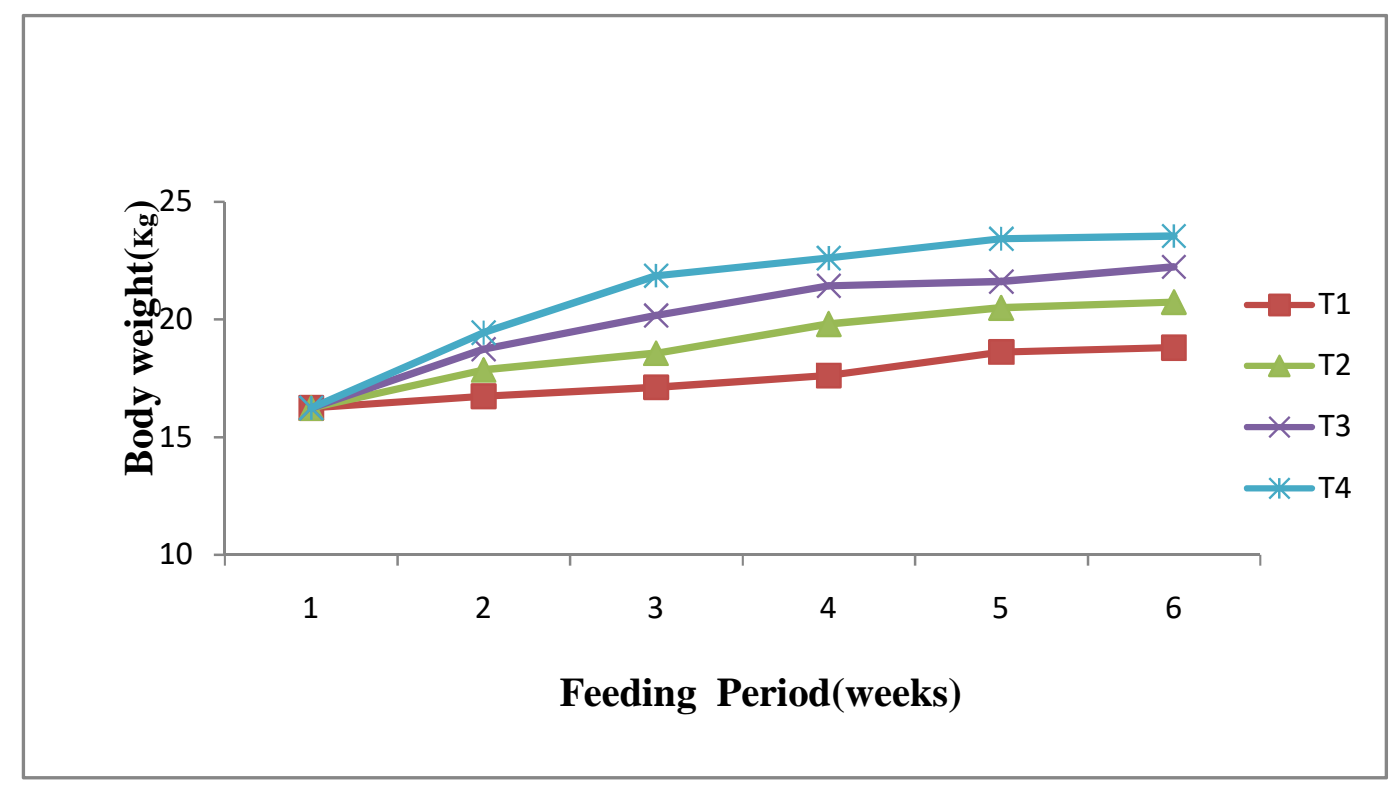

Figure 1: Live weight change of grazing goats supplemented with sweet potato vine silage

\section{Conclusion}

A study was carried out to determine supplementation effects of sweet potato vine silage on growth performances of grazing local goats. In the current feeding trial study, the increased supplementation of sweet potato vine silage revealed increased performance of grazing local goats. The intake of DM, OM and CP of sweet potato vine silage increased with increasing levels of sweet potato vines silage supplementation. Intake of DM increased from $78 \%$ to $234 \%$ with increasing levels of SPVS supplementation. Increased daily DM intake was manifested in superior live weight gains where best results were obtained in supplemented than in nonsupplemented ones. Feed resources are crucial in the livestock production system of the smallholder farmers. Taking this into consideration, the extension and institutional systems are mandated to commit in alleviating the widespread barriers hindering the performance of the existing available feed resources and the producers could benefit from the livestock they keep. 


\section{Acknowledgements}

The authors would like to thank the technical contributions of staff from Southern bureau of livestock and fishery resource, Loma Wored experts of small ruminants and farmers in research site. The assistance from staffs and farmers during 90 days trails in Loma Woreda at research site are greatly appreciated for selection, facilitation, data recording and sample collection.

\section{Funding}

The financial support for this study was provided by Southern Nation Nationality and People Regional State Government, Bureau of livestock development.

\section{Author information}

1. Yaekob Lorato (corresponding author)

Lecturer and Researcher in Animal Production at Wolaita Sodo University, Ethiopia

Address: Wolaita Sodo University Department of Animal and Range Science E-mail:- yakob.lorato@yahoo.com

2. Amare Abera: (Co-Authors)

Coordinator of Development and Research Director of Animal Production Sciences Address: $\quad$ Senior Expert in Southern Nation, Nationality and People Regional State Bauru of Livestock and fishery Resource Development

\section{Authors' contributions}

E-mail: amuab@gmail.com

The experiments were planned by Yaekob Lorato and executed by Amare Abera with assistance from Livestock Research institute. The first draft of the manuscript was written by Yaekob Lorato and was edited by Amare Abera. experimental design, data collation, manuscript preparation and proof reading and the final version of the manuscript was prepared by Yaekob Lorato. The authors read and approved the final manuscript.

\section{Availability of data and materials}

The dataset analysed during the current study will be available from the corresponding author on reasonable request, after timely full publication of results from other aspects of the experiment.

\section{Ethics declarations}

\section{Ethics approval and consent to participate}

All experimental procedures followed the Guide for the Care and Use of Agriculture Animals in Research and Teaching and approved by the Institutional Animal Care and Use Committee of Wolaita Sodo University. There was no use of human participants, data, or tissues.

\section{Consent for publication}

All authors provide consent to publish this article.

\section{Competing interests}

The authors declare that they have no competing interests. 


\section{Author details}

1. Yaekob Lorato: Head, Departments of Animal and Range Science, Wolaita Sodo University, Ethiopia. Full time researcher and Lecturer in University.

2. Amare Abera: Coordinator of Development and Research Director of Animal Production Sciences. Senior Expert in Southern Nation, Nationality and People Regional State Bauru of Livestock and fishery Resource Development

\section{REFERENCES}

1. Netsanet Beyero.2006. Sweet potato vines in smallholder livestock feeding system and concentrate replacement value of sweet potato vines in goat feeding. Msc Thesis, University of Hawassa, Hawassa, Ethiopia

2. Valérie Heuzé, Gilles Tran, Philippe Hassoun, 2011. Sweet potato (Ipomoea batatas) forage. Feedipedia.org and Tables Régions Chaudes. A project by INRA, CIRAD and AFZ with the support of FAO. Last updated on March 21, 2011, 23:32

3. LWLFRO, 2018. Annual reports of Loma Woreda Livestock and Fishery resource Development office, 2018.

4. Stathers,T., 2005. Manual for Sweet potato Integrated Production and Pest Management Farmer Field Schools in sub-Saharan Africa. International Potato Center, Kampala, Uganda. pp168 +xxxi. ISBN 9970-895-01-X

5. SAS, 2003. Statistical Analysis System. Institute Inc., Cary, NC, USA

6. Tegene Negesse, Senbeto Funto and Adugna Tolera 2010.Forage Dry matter yield and Nutritive value of the natural pasture of Umbulo Wacho Water shade, Southern Ethiopia. East African journal Science.4 (1)1-10.

7. Tikuuneh Zelalem. 2009. Assessment of Livestock production system and feed resources in Gonder Zuria woreda, Amhara Region. M.sc. Thesis, Hawassa University, Ethiopia.

8. Gebreziabher, 2013. Chemical composition and In vitro Digestibility of Fresh, Dried and ensiled vines of sweet potato (ipomea batatas) cultivars. An Msc. Thesis presented in school of Graduate studies of Hawassa University, Hawassa, Ethiopia.

9. Dinku Geta, 2013. Nutritive value of Natural Pasture from Grazing Land, two varieties of sweet potato Morphological Fractions, and Effects of Feeding Sweet potato vines to Grazing Sheep. Msc Thesis, University of Hawassa, Hawassa, Ethiopia. 
Figures

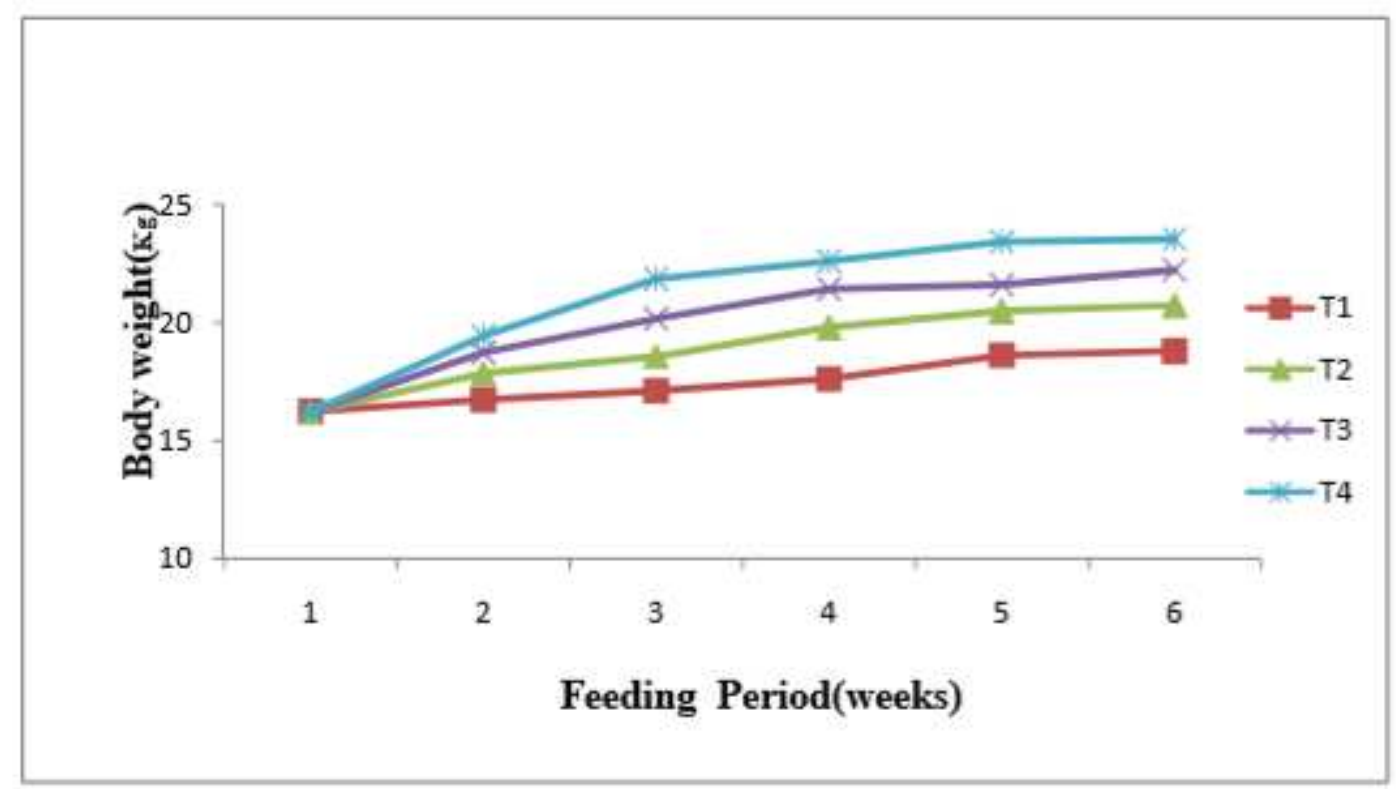

\section{Figure 1}

Live weight change of grazing goats supplemented with sweet potato vine silage. 